\title{
MAIDON RASVAN JA VALKUAISEN KESKINÄISESTÄ SUHTEESTA.
}

\author{
T. LONKA. \\ Suomen Karjanjalostusyhdistys, Tikkurila.
}

Saapunut 13. 12. 1952.

Kotoisten väkirehujen verraten alhainen valkuaispitoisuus ja enemmän valkuaista sisältävien heinien ja AIV-rehun suuri täyttävyys tekevät vaikeaksi järjestää runsastuottoisille lehmille riittävän väkevää ja samalla valkuaispitoista ruokintaa ilman ulkolaisia valkuaisrehuja. Kun ulkolaiset valkuaisrehut ovat tunnetusti kalliita, ne kohottavat maidon tuotantokustannuksia, jotapaitsi väkirehujen maahantuonti on kansantalouden kannalta vähemmän toivottavaa. Niiden käyttö on sitäkin epätaloudellisempaa, kun suurin osa tuottajista voi myydä vain maidon rasvan ja kuorittu maito on käytettävä sellaisiin tarkoituksiin, ettei siitä saada tuotantokustannuksia vastaavaa hintaa. Juuston valmistuksessa, joka tulevaisuudessa epäilemättä lisääntyy, maidon valkuainen tai tarkemmin sanottuna kaseiini on tärkeä raaka-aine. Siinäkään tapauksessa, että pääosa maidosta valmistettaisiin juustoksi, meidän ei kuitenkaan kannattaisi tuottaa ulkolaisia väkirehuja, jollei nimenomaan riittävän valkuaispitoisen ja samalla kylliksi konsentroidun ruokinnan järjestäminen sitä vaatisi. Toisin sanoen meidän ei kannata tuottaa maahan valkuaisrehuja pelkästään sen vuoksi, että niiden valkuainen täällä jalostetaan juustoksi. Jokainen ulkoa tuotu väkirehukilo vähentää nimittäin kotoisista rehuista saatua korvaushintaa, mikäli se ei samalla lisää kotoisten rehujen hyväksikäyttöä.

Missä määrin valkuaisrehuja ruokinnassa tarvitaan riippuu tietenkin maidon kokoomuksesta. Jos maito sisältää niin paljon valkuaista rasvaan verrattuna, että ruokintaa ei voida järjestää kotoisilla rehuilla riittävän valkuaispitoiseksi ilman, että kuiva-aineen määrä tulee liian suureksi, on valkuaisrikkaiden väkirehujen käyttö välttämätöntä ja silloin ne tietenkin lisäävät kotoisten rehujen hyväksikäyttöä. Jos maito sen sijaan sisältää valkuaista vain sen verran, että tarvittava valkuainen saadaan kotoisista rehuista ilman, että kuiva-ainemäärä tulee liian suureksi, eivät ulkolaiset väkirehut lisää kotoisten rehujen hyväksikäyttöä. Tällöin tilalta saatavat rehut voidaan jalostaa maidoksi halvemmin kustannuksin kuin ensiksi mainitussa tapauksessa. Taloudellisimpia olisivat siis ne eläimet, joiden maidossa olisi vain niin paljon valkuaista rasvaan verrattuna, että ne kykenisivät 
antamaan suuriakin maitomääriä pelkästään kotoisilla väkirehuilla, heinillä ja AIV-rehulla sekä juurikasveilla. Mikäli tähän suuntaan voitaisiin eläimiä jalostaa se olisi siitosvalinnassa otettava huomioon.

Aikaisemmin on yleisesti ollut se käsitys, että maidon rasvapitoisuuden ja valkuaispitoisuuden välillä vallitsisi määrätty kiinteä vuorosuhde, joka olisi kaikilla eläimillä samanlainen. Tähän käsitykseen perustuvat myös ruokintataulukkomme, joissa tuotantorehun tarve on laskettu rasvapitoisuuden perusteella. Koska yksityisten lehmien maidosta tehdyt analyysit, sikäli kun niitä on tehty, samoin kuin sekamaitonäytteiden tulokset viittasivat siihen, että maidon rasva- ja valkuaispitoisuuden keskinäinen suhde saattaisi olla ainakin jossakin määrin myös yksilöllınen ominaisuus, suoritin aikanaan Maatalouskoelaitoksen kotieläinjalostusosastolla tätä koskevia tutkimuksia. Nämä tutkimukset (3) osoittivat, että maidon rasvaja valkuaispitoisuuden suhde vaihtelee eri eläimillä ja eri tarkastuskerroilla hyvin paljon, vieläpä niin paljon, että valkuaispitoisuuden määrääminen rasvapitoisuuden perusteella johtaa yksityistapauksissa jopa kokonaisen prosentin ja sitäkin suurempiin virheisiin. Vaikka ulkonaisilla tekijöillä näyttikin olevan suuri osuus tässä muuntelussa, oli kuitenkin ilmeistä, että se on myös yksilöllinen, perintötekijöistä riippuva ominaisuus. Tätä käsitystä ovat vahvistaneet monet muut, erityisesti ruotsalaisten BonniERin ja HANssonin $(1,2)$ identtisillä kaksosilla suorittamat laajat ja perusteelliset tutkimukset.

Kysymystä käsittelevät tutkimukset viittaavat siis siihen, että maidon rasvaja valkuaispitoisuus periytyvät ainakin osaksi itsenäisesti toisistaan riippumatta. Sen sijaan niiden perusteella ei vielä selviä onko kysymyksessä oleva perinnöllinen muuntelu niin suuri, että käytännössä on mahdollista kehittää eläimiä tässä suhteessa haluttuun suuntaan. Tähän voidaan saada vastaus ainoastaan siten, että suoritetaan analyysejä niin monen yksityisen lehmän maidosta, että on toiveita saada esille myös äärimmäisiä komtinaboita ja siten arvioida siitosvalinnan mahdollisuuksia. Koska eläimet eri maissa ja eri roduissa saattavat olla tässä suhteessa erilaisia, on tutkimukset myös suoritettava nimenomaan siinä eläinaineksessa, jossa siitosvalintaa tähän ominaisuuteen nähden aiotaan harjoittaa, ennenkuin jalostuksen käytännöllisistä mahdollisuuksista päästään selville. Näin ollen kysymys on myös meillä selvitettävä erikseen. Tässä tarkoituksessa on kirjoittaja jatkuvasti kerännyt lisäaineistoa meikäläisestä lehmäaineksesta. Tähän mennessä loppuun suoritetuista analyyseistä esitetään seuraavassa eräitä ennakkotietoja.

Kuten aikaisemmassakin tutkimuksessa koelehmien maito on analysoitu yhden lypsykauden aikana jokaisen tarkastuslypsyn yhteydessä otetuista maitonäytteistä. Analyysit on suoritettu Valion Tampereen laboratoriossa ja on valkuaispitoisuus määritetty n.s. formaliinititrausta käyttäen sekä maidon rasvapitoisuus Gerbermenetelmällä. Mainitulla menetelmällä tehtyjen valkuaismääritysten tarkkuudesta voidaan tehdä useitakin huomautuksia. Formaliinititraus antaa kuitenkin mm. ruotsalaisen Thomén (5) tutkimusten mukaan varsin tarkkoja arvoja. Lisäksi on otettava huomioon, että yksilöiden välisten perinnöllisten erojen täytyy olla verraten suuret ennenkuin siitosvalintaa kannattaa käytännössä ajatella. Täten niiden myös täytyy myönteisessä tapauksessa tulla esille jonkinverran epätarkemmallakin mene- 
telmällä, jotapaitsi formaliinititraus on ainakin toistaiseksi tarkin menetelmä, joka samalla on niin yksinkertainen, että sen käyttäminen siitosvalinnassa voisi tulla kysymykseen.

Aineisto käsittää kaikkiaan 75 SK-lehmää 12 karjasta. Eri tarkastuskierroilta saatuja tuloksia on kuitenkin huomattavasti vähemmän kuin lehmien kokonaisluku edellyttää. Tämä aiheutuu ensiksikin siitä, että meillä ei elokuussa suoriteta tarkastuslypsyjä ja lisäksi erilaisista syistä johtuen jokaisesta koelehmästä ei kaikkina tarkastuskertoina ole saatu maitonäytteitä. Koska puuttuvat kuukaudet sattuvat eri lehmillä eri aikaan lypsykautta, ei tällä seikalla ole sanottavaa vaikutusta tuloksiin. Koe-eläimet on myös pyritty valitsemaan ruokinnaltaan erilaisista karjoista, jotta ne tässä suhteessa edustaisivat keskinäytettä. Niiden poikima-ajat ovat jakautuneet kalenterikuukausille seuraavasti:

\begin{tabular}{l|r|r|r|r|r|r|r|r|r|r|r|r|c} 
Kuukausi & I & II & III & IV & V & VI & VII & VIII & IX & X & XI & XII & Yht. \\
\hline Lukumäärä & 10 & 6 & 11 & 11 & 7 & 6 & - & - & 5 & 6 & 11 & 2 & 75
\end{tabular}

Koelehmät ovat poikineet eri aikaan vuodesta ja ilmeisesti likimain siinä suhteessa kuin meillä yleisesti on asian laita. Se, ettei heinä- ja elokuussa ole poikinut yhtään koelehmistä, vastaa todellisuutta myös sikäli, että tällöin varsin pieni osa lehmistä poikii.

Aineiston perusteella on laskettu kunkin tuotantokuukauden rasva- ja kaseiinipitoisuuden keskiarvot $\left(\mathrm{M}_{ \pm} \mathrm{m}\right)$ sekä hajonnan $(\sigma)$ ja muuntelukertoimen (v) arvot. Lisäksi on laskettu rasva- ja kaseiinipitoisuuden väliset vuorosuhdekertoimet $\left(\mathrm{r} \_\mathrm{m}\right)$ niin ikään erikseen jokaisena tuotantokuukautena. Näin saadut tulokset on esitetty oheisessä taulukossa ja kuviossa.

Rasva- ja kaseiinipitoisuuden suhde lypsykauden eri kuukausina

The relation fat and casein percentage in the different production months.

\begin{tabular}{|c|c|c|c|c|c|c|c|c|}
\hline \multirow{2}{*}{$\begin{array}{l}\text { Tuot. } \\
\text { kuuk. } \\
\text { Prod. } \\
\text { months }\end{array}$} & \multirow{2}{*}{$\begin{array}{c}\text { Lehmä- } \\
\text { luku } \\
\text { Cows }\end{array}$} & \multicolumn{3}{|c|}{ Rasva- $\%$ - Fat- $\%$} & \multicolumn{3}{|c|}{ Kaseiini-\% - Casein-\% } & \multirow{2}{*}{$\begin{array}{l}\text { Vuorosuhde } \\
\text { correlation } \\
\text { coefficient } \\
\mathrm{r} \pm \mathrm{m}\end{array}$} \\
\hline & & $\mathrm{M} \pm \mathrm{m}$ & $\sigma$ & $\mathrm{v}$ & $\mathrm{M} \pm \mathrm{m}$ & $\sigma$ & $\mathrm{v}$ & \\
\hline I & 40 & $4.21 \pm 0.09$ & 0.55 & 13.06 & $2.63 \pm 0.06$ & 0.36 & 13.69 & $+0.13 \pm 0.16$ \\
\hline II & 72 & $4.04 \pm 0.07$ & 0.57 & 14.11 & $2.35 \pm 0.02$ & 0.20 & 8.51 & $+0.16 \pm 0.11$ \\
\hline III & 64 & $4.16 \pm 0.08$ & 0.67 & 16.11 & $2.36 \pm 0.02$ & 0.20 & 8.47 & $+0.46 \pm 0.08$ \\
\hline IV & 62 & $4.15 \pm 0.08$ & 0.65 & 15.66 & $2.38 \pm 0.02$ & 0.18 & 7.56 & $+0.41 \pm 0.11$ \\
\hline V & 54 & $4.16 \pm 0.09$ & 0.64 & 15.38 & $2.40 \pm 0.03$ & 0.21 & 8.75 & $+0.47 \pm 0.11$ \\
\hline VI & 63 & $4.43 \pm 0.08$ & 0.67 & 15.12 & $2.49 \pm 0.03$ & 0.23 & 9.24 & $+0.35 \pm 0.11$ \\
\hline VII & 53 & $4.44 \pm 0.06$ & 0.47 & 10.59 & $2.54 \pm 0.03$ & 0.27 & 10.63 & $+0.27 \pm 0.12$ \\
\hline VIII & 59 & $4.57 \pm 0.09$ & 0.67 & 14.66 & $2.61 \pm 0.03$ & 0.25 & 9.58 & $+0.56 \pm 0.09$ \\
\hline IX & 64 & $4.82 \pm 0.09$ & 0.76 & 15.77 & $2.73 \pm 0.03$ & 0.23 & 8.42 & $+0.47 \pm 0.10$ \\
\hline $\mathrm{X}$ & 46 & $5.00 \pm 0.12$ & 0.79 & 15.80 & $2.89 \pm 0.04$ & 0.25 & 8.65 & $+0.35 \pm 0.13$ \\
\hline $\mathrm{XI}$ & 29 & $5.02 \pm 0.15$ & 0.82 & 16.33 & $2.84 \pm 0.06$ & 0.35 & 12.32 & $+0.67 \pm 0.10$ \\
\hline
\end{tabular}




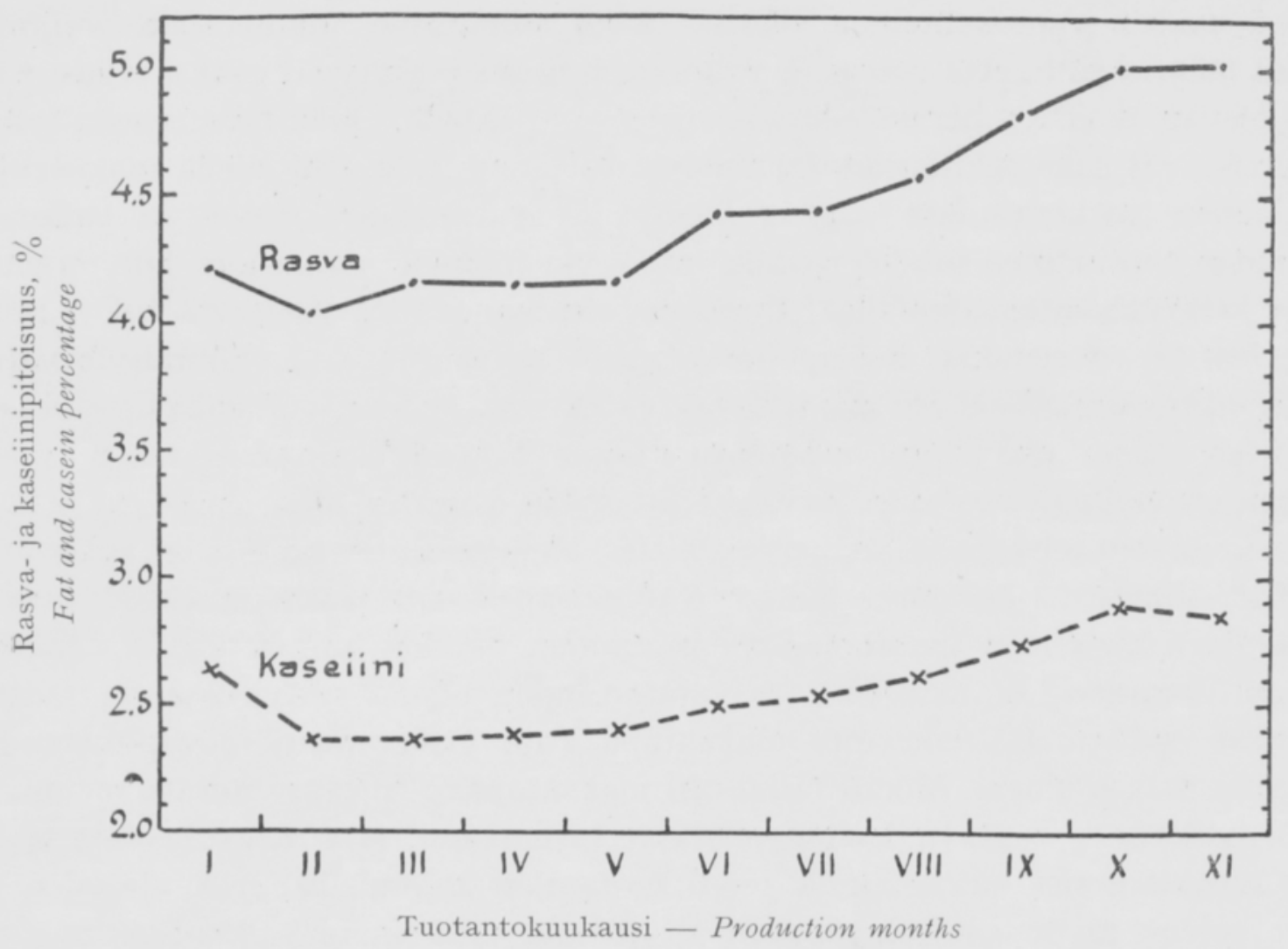

Rasva- ja kaseiinipitoisuus eri tuotantokuukausina.

The fat and casein percentage of the different months of lactation.

Tulosten mukaan sekä rasva- että kaseiinipitoisuus on ensimmäisenä kuukautena poikimisen jälkeen jonkinverran korkeampi kuin toisena kuukautena, mutta alkaa toisesta kuukaudesta lähtien nousta lypsykauden loppua kohden. Rasva- ja kaseiinipitoisuuden muuttuminen lypsykauden kuluessa näyttää keskiarvojen mukaan seuraavan likimain toisiaan. Kuitenkin on kaseinipitoisuuden suureneminen melkoisesti tasaisempaa kuin rasvapitoisuuden. Erityisesti on merkillepantava, että rasvapitoisuuden muuntelu on noin kaksi kertaa suurempi kuin kaseiinipitoisuuden, kuten $\sigma: n$ ja varsinkin v:n arvoista nähdään. Tämä viittaa siihen, että maidon valkuaispitoisuuden perinnöllinen muuntelu on pienempi kuin rasvapitoisuuden, joskin on ilmeistä, että myös ulkonaiset tekijät aiheuttavat siinä vähemmän muuntelua kuin rasvapitoisuudessa.

Huolimatta siitä, että näinkin pienessä aineistossa rasvan ja kaseiinin keskiarvot seuraavat melko tarkasti toisiaan lypsykauden kuluessa, poikkeavat yksityistapaukset hyvin paljon tästä yleissäännöstä. Niinpä niiden välille onkin saatu verraten pienet vuorosuhteet. Erityisen pieni on vuorosuhde kahtena ensimmäisenä kuukautena, jolloin rasvapitoisuuden perusteella ei yksityistapauksissa sanottavasti voida päätellä paljonko maito sisältää valkuaista. Myöhempinä kuukausina vuorosuhde on jo kiinteämpi ja valkuaispitoisuuden määrittelyyn rasvan perusteella on jo suuremmat mahdollisuudet, mutta yksityistapauksissa voivat virheet vieläkin olla hyvin suuret, siksi pieni myöhemminkin on vuorosuhdekerroin. 
Missä määrin vuorosuhteiden alhaiset arvot aiheutuvat ulkonaisista tekijöistä ja missä määrin siitä, että rasva- ja valkuaispitoisuus periytyvät osaksi erikseen, ei käsillä olevan aineiston perusteella voida tarkasti päätellä. Joka tapauksessa tulokset vahvistavat sekä tekijän aikaisemmasta tutkimuksesta että edellä mainittujen ruotsalaisten tutkimuksista saatua käsitystä, että maidon rasva- ja valkuaispitoisuuden keskinäinen suhde on osaksi myös yksilöllinen ominaisuus, jota on mahdollista kehittää siitosvalinnalla haluttuun suuntaan. Tätä käsitystä tukee myös POIJARVEN (4) suorittamat kokeet, jotka ovat osoittaneet, että valkuaisyliruokinnalla ja -aliruokinnalla ei ole mainittavaa vaikutusta maidon valkuaispitoisuuteen.

Kuten alussa mainittiin, maidontuotannon taloudellisuutta ajatellen meillä olisi maidon valkuaispitoisuus pyrittävä pitämään verraten alhaisena niin, että se vastaisi kotoisten rehujen valkuaispito'suutta. Meijerimiesten piirissä on viime vuosina alettu kiinnittää huomiota maidon valkuaispitoisuuteen siinä mielessä, että se olisi otettava huomioon juustomeijereihin tuodun maidon hinnoittelussa. Maidon kaseiinipitoisuuden huomioiminen rasvapitoisuuden ohella tilityksissä on juustomeijereissä epäilemättä oikeampi maksutapa kuin yksinomaan rasvapitoisuuden perusteella maksaminen. Mikäli tällaiseen maksutapaan tulevaisuudessa mennään, on samanaikaisesti saatava karjanomistajat tajuamaan, että maksutavasta huolimatta arvokkaimpia siitoseläimiä ovat tuotannon taloudellisuutta ajatellen ne eläimet, joiden maito sisältää rasvaan verrattuna vähemmän valkuaista kuin ne, joiden maidossa sitä on enemmän. Tällainen näennäısest' ristiriitaisen siitosvalinnan ymmärrettäväksi tekeminen tulee käytännössä epäilemättä tuottamaan vaikeuksia.

KIRJALLISUUTTA.

(1 Bonnier, G. ja Hansson, A. 1946. Studies on monozygous cattle twins. VII. On the genetical determination of the interdependecy between the percentage of fat, protein, and lactose in the milk. Acta Agr. Suec. 2, p. 171-184.

(2) Hansson, A. ja Bonnier, G. 1949. Further studies on the genetical determination of the composition of cows' milk with regard to fat, protein and lactose. Ibid. 3, p. 179-188.

(3) LonkA, T. 1947. Can the relation between fat and protein in milk be changed by selective breeding. Maataloust. aikakausk. 19, p. 8-21.

(4) PoIJÄRvi, I. 1952. Koe rehuannoksen erilaisten valkuaismäärien vaikutuksesta maidon valkuaispitoisuuteen sekä tuotettuihin maito- ja valkuaismääriin. Karjatalous, 23, p. $553-557$.

(5) Тноме́, K. E. 1950. Mjölkens äggvitehalt och därmed sammanhängande förhållanden. Svenska Mejeritidn. $35-36$.

\section{Miopiston}


SUMMARY.

THE RELATION BETWEEN FAT AND PROTEIN IN MILK.

Preliminary report.

By T. LONKA

The Finnish Cattle Breeders' Association, Tikkurila, Finland.

The investigation involves 75 cows from 12 herds of the race of Finnish Cattle. The fat and casein content of the milk of these cows was determined once a month during one lactation period. For various reasons it has been impossible to get milk samples from every cow every month. Therefore the number of analyses is smaller than the number of cows. The casein content was determinet by using formalin method and the fat content by using the Gerber method. The mean percentages of fat and casein have been calculated from the results and the correlation coefficients separately for every production month. The results are given in the table and the figure. 